\title{
Monitoring of herpesvirus anguillae (AngHV-1) infections in the European eel in north-west Poland
}

\author{
NGUYEN THUC TUAN*,**, JOLANTA KEMPTER*, REMIGIUSZ PANICZ**

\begin{abstract}
*Department of Aquaculture, **Department of Meat Technology, West Pomeranian University of Technology in Szczecin, Kazimierza Królewicza 4, 71-550 Szczecin, Poland

${ }^{* * *}$ Faculty of Agriculture-Forestry-Fisheries, Vinh University, 182 Le Duan street, Vinh City, Nghe An province, Vietnam
\end{abstract}

Nguyen T. T., Kempter J., Panicz R.

\section{Monitoring of herpesvirus anguillae (AngHV-1) infections in the European eel in north-west Poland}

\section{Summary}

The European eel (Anguilla anguilla) is an economically important species in Poland, not only due to the quality and price of its meat, but also due to the eel stock management plan implemented since 2010. However, the imported juvenile eels for reintroduction are directly introduced into waters or reared in fish farms without necessary monitoring of the health status, especially for hazardous and pathogenic viruses. The study was conducted in the second half of 2014 using the European eels collected from Poland (Dąbie Lake, Szczecin Lagoon, hatcheries) and Denmark, mainly from importers and organizations producing material for reintroduction. A total of 256 samples were analysed including gills, liver, kidney, spleen, intestine and heart. Detection of the AngHV-1 was performed using pair primers designed to amplify the gene fragment encoding the viral DNA polymerase. Each PCR product was confirmed by bidirectional sequencing and sequence alignment with GenBank sequences. Obtained results indicate that the infection status of the eels imported to Poland is in the range of $0 \%$ to $100 \%$, with the highest percentage of asymptomatic carriers among the fish imported from Denmark for the purpose of reintroduction and rearing. The eels collected in natural waters demonstrated an AngHV-1 infection rate of 30\% (Dąbie Lake) and 40\% (Trzebież). Bioinformatics analysis demonstrated that all these sequences were identical and represented the haplotype characterized for the first time in Poland. The intensity of eel reintroduction in Poland is $\mathbf{1 . 2}$ million individuals per year, which permits a conclusion that the species is important for the fishing economy and should be monitored against AngHV-1. The demonstrated existing high risk posed by mass kills of the European eel in domestic waters after the introduction of the herpesvirus AngHV-1 from imported fish.

Keywords: reintroduction programme, Anguilla anguilla, AngHV-1, imported fish, herpesvirus

The European eel (Anguilla anguilla L.) is an economically important species in Poland, not only due to the quality and price of its meat, but also due to the eel stock management plan implemented since 2010 . The habitat of this species in Poland includes almost all types of waters; however, of major importance are transitional waters, mainly of the Vistula Lagoon and the Szczecin Lagoon, and lakes located in the northern part of the country (11). The average size of eel catches in the years 2009-2011 in the catchment areas of the Oder and Vistula rivers was 201.1 tonnes. However, in 2011, a downward trend in the catches to 170.4 tonnes was observed in both catchment areas. A similar phenomenon is observed in the case of eel catches in marine and coastal waters, in which the average value in 2009-2011 was 40.9 tonnes, with the lowest value of 31.2 tonnes obtained in 2011 (12). The intensity of eel reintroduction in Poland is 1.2 million individuals per year, which permits a conclusion that the species is important for the fishing economy. One of the main threats for fisheries and aquaculture are viruses, especially herpesviruses, which form a group of the most frequently occurring DNA viruses in fish (7). The virus was isolated in 1985 from ill European and Japanese eels, cultured in EK-1 and EO-2 cell lines and identified as Herpesvirus anguillae (AngHV-1) (14). The clinical signs of AngHV-1 infection are characterized by intense reddening of the head area, especially the mouth. Moreover, petechiae at the base of the fins, enlarged kidney and spleen, as were as necrosis of the skin, gills, liver and spleen have been observed (5). Neither in Poland nor in other EU countries (the Netherlands, Germany) is there an obligation to conduct tests for the detection of AngHV-1 (EU $2006 / 88 / E C)$. This means that there is no legal barrier prohibiting the introduction of the European eel carrying identified AngHV-1 genome into open waters. In Poland imported material for reintroduction is directly introduced into waters or reared in fish farms without 
virus monitoring. Therefore, the aim of the study was to verify the health status of the European eel distributed in north-west Poland to provide information on hazardous and pathogenic AngHV-1.

\section{Material and methods}

The study material consisted of 86 eels obtained in the second half of 2014 from importers and organizations producing material for reintroduction. The size of the eels ranged from 12 to $88 \mathrm{~cm}$. The study was conducted using European eels collected from Polish fishermen using fyke nets in the waters of Dąbie Lake $(n=20)$ and the Szczecin Lagoon $(\mathrm{n}=15)$. Other samples were juvenile eels imported for rearing from Denmark and purchased from a Polish importer (Dzwonowo, $\mathrm{n}=6$; Koszalin branch of Polish Angling Association (PZW), $n=31$; and Stepnica, $n=9$ ). Eels originating from the experimental fisheries station (RSD) Dolna Odra $(\mathrm{n}=5)$ were intended for pre-rearing. After being transported to the rearing centre, they had contact with the cooling water from the Dolna Odra power plant in Nowe Czarnowo. The study was conducted in 2015 in the genetics laboratory of the Department of Aquaculture, West Pomeranian University of Technology, Szczecin, Poland.

Tab. 1. Primer pair used in the study to detect the AngHV-1 genome

\begin{tabular}{|l|l|c|}
\hline \multicolumn{1}{|c|}{ Primer name } & \multicolumn{1}{|c|}{ Primer sequence } & Reference \\
\hline HVAPOLVPSD & 5'-GTG TCG GGC TTT GTG GTG C-3' & Rijsewijk et al. (13) \\
\hline HVAPOLOOSN & 5'-CAT GCC GGG AGT CTT TTT GAT-3' & \\
\hline
\end{tabular}

Tab. 2. Comparison of the number of samples containing AngHV-1 according to the method of DNA isolation

\begin{tabular}{|l|c|c|c|}
\hline \multicolumn{1}{|c|}{ Collection site } & \multirow{2}{*}{$\begin{array}{c}\text { Sample } \\
\text { type }\end{array}$} & \multicolumn{2}{|c|}{$\begin{array}{c}\text { Number of AngHV-1-PCR-positive samples } \\
\text { vs. total samples (\% of PCR positive eels) } \\
\text { Column }\end{array}$} \\
\hline Dzwonowo $(\mathrm{n}=6)$ & Gills & $0(0 \%)$ & $0(0 \%)$ \\
& Pool & $0(0 \%)$ & $0(0 \%)$ \\
\hline Dąbie Lake $(\mathrm{n}=20)$ & Gills & $6(30 \%)$ & $5(25 \%)$ \\
\hline Trzebież $(\mathrm{n}=15)$ & Gills & $6(40 \%)$ & $4(27 \%)$ \\
\hline Denmark $(\mathrm{n}=9)$ & Gills & $6(66 \%)$ & $4(44 \%)$ \\
\hline PZW Koszalin $(\mathrm{n}=31)$ & Gills & $29(94 \%)$ & $19(61 \%)$ \\
\hline RSD Dolna Odra $(\mathrm{n}=5)$ & Pool & $22(71 \%)$ & $15(48 \%)$ \\
\hline $\begin{array}{l}\text { Positive samples/total } \\
\text { number of samples }\end{array}$ & Pool & $5(100 \%)$ & $3(60 \%)$ \\
\hline
\end{tabular}

\begin{tabular}{ccccccc}
\hline 10 & 20 & 30 & 40 & 50 & 60 & 70 \\
\hline
\end{tabular}

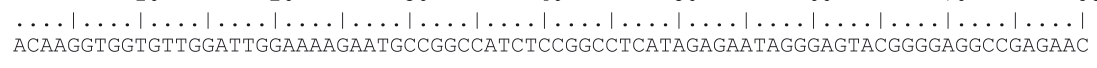
$\begin{array}{llllllll}90 & 100 & 110 & 120 & 130 & 140 & 150 & 160\end{array}$ CTCTACACCATCCTCCTACACAAGAGTGTGGAGACCGGGTGACCAGGTTTACGACGTACACGTCTTCCAGCCTCCGCCA

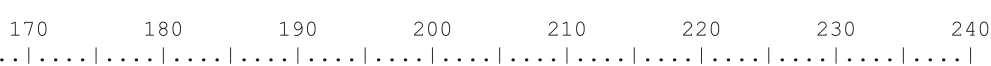

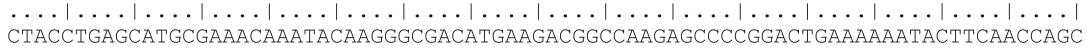

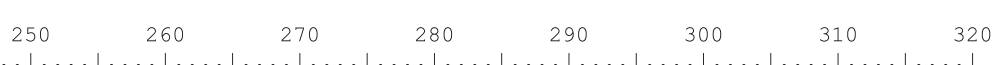
$\ldots \ldots|\ldots| \ldots|\ldots| \ldots|\ldots| \ldots|\ldots| \ldots|\ldots| \ldots|\ldots| \ldots|\ldots| \ldots|\ldots| \ldots|\ldots| \ldots|\ldots|$ 330 340 350

GGGCGACAAAAGATCCTTATAGTGGAGGACGTG

Fig. 1. Fragment of the AngHV-1 DNA polymerase gene sequence
From each of the 86 obtained individuals, gill slices were taken. As for the imported individuals, fragments of internal organs (liver, kidney, spleen, intestine and heart) were sampled, combined at an equal weight ratio and treated as a single sample (pool). A total of 256 samples were analysed. DA was isolated from each sample using the peqGOLD (PeqLab, Germany) and DNAzo The qualitative and quantitative assessment of the obtained A was carried out by electrophoresis of DNA isolates $.5 \%$ agarose gel followed by absorbance measureThermo Scientific). Detection of the gene fragment encoding viral DNA polymerase AngHV-1 was conducted using primers HVAPOLVPSD and HVAPOLOOSN, according the procedure developed by Rijsewijk et al. (13) (Tab. 1). in $1.5 \%$ a sequencing of each PCR product (Genomed, Poland). The results of sequencing were analysed using BLAST, MEGA5 and BioEdit software $(1,6,16)$.

\section{Results and discussion}

The qualitative and quantitative analysis of the obtained DNA isolates demonstrated that the column method provided isolates characterized by a higher degree of purity. The purity of DNA obtained using this method was in the correct range of 1.8-2.0, while that of DNA obtained using DNAzol was often below 1.8. As a consequence, differences in the number of positive samples obtained via PCR were observed. Overall, the amplification reactions yielded $30 \%$ and $20 \%$ of specific PCR products from the isolates obtained using the column method and DNAzol, respectively (Tab. 2). Bi-directional sequencing yielded sequences of $353 \mathrm{bp}$. Bioinformatics analysis demonstrated that all these sequences were identical and represented the haplotype characterized for the first time in Poland by Kempter et al. (9). The haplotype is the most common variant of a fragment of the AngHV-1 DNA polymerase gene. It is fully homologous with the sequences obtained from the analysis of eel samples from China or Denmark and GenBank records (e.g. AF333066, FJ940765) $(3,9,13)$. The obtained fragment of the AngHV-1 DNA polymerase gene sequence is presented in Fig. 1. For unknown reasons, the number of glass eels migrating to the coasts of Europe is decreasing. In Germany, the decrease is estimated at $1 / 10$, while in France, at 1/7 of the number observed in 1980s (15). In numerous European countries, eel stock management plans are implemented, including reintroduction of specified quantities of this species into waters. However, reintroduction plans pose a risk of introducing a pathogen that may potentially infect other eels. Such risk is 
posed by herpesviruses which occur in both humans and animals. Herpesvirus infections are dangerous as they can occur in latent form or remain in the fish and in the environment for a long time after the recovery of the fish. This leads to a permanent presence of herpesviruses in the aquatic environment, but often also in bottom sediments or submerged plants. Much more dangerous is the presence of herpesviruses in invertebrates (10), due to the potential secondary transmission of the virus to the fish.

According to the results of this study, the problem of herpesvirus infection in eels due to the presence of AngHV-1 regards not only the fish that had contact with waters from rearing sites or natural waters in which they were pre-reared. The infection may originate from imported eels, thus the virus is introduced into the environment in which the eels may not have had previous contact with AngHV-1. In light of the fact that eel mortalities have been observed in Europe in the last 10 years and eel population has declined (5), the monitoring of the health of eels, with a special focus on viral diseases, should be a subject of particular attention. Eels imported to Poland, according to a report of 2012, are free of EVEX, AnHV-1 and other viruses pathogenic for the fish species produced in Polish aquaculture (12). However, as demonstrated in this study, the infection status of the eels imported to Poland is in the range of $0 \%$ to $100 \%$, with the highest percentage of asymptomatic carriers among the fish imported from Denmark for the purpose of reintroduction (Koszalin branch of PZW) and rearing (RSD Dolna Odra). The eels collected in natural waters demonstrated an AngHV-1 infection rate of 30\% (Dąbie Lake) and 40\% (Trzebież). The cases of positive results indicate that the waters of one of the largest lakes in north-western Poland and the waters of the Szczecin Lagoon are not free of AngHV-1. Reintroduction of eels in the zones in which no fish infected with AngHV-1 have been found is highly contraindicated in such epizootic circumstances. In England, the presence of AngHV-1 in wild European eels was confirmed for the first time in 2009-2010 (2). In contrast to the situation in Poland, the death of eels occurred in waters at $17-19.4^{\circ} \mathrm{C}$ with symptoms typical of herpesvirus infections. According to the authors, detection of HVA in England is of very high importance in the implementation of a conservation and management programme focused on this species. It is also a determining factor in the implementation of reintroduction plans. An analysis of 140 eels from northern Germany (10) revealed the presence of AngHV-1 only in the eels from marine waters (Helgoland). The eels did not reveal any clinical signs, which confirms their carrier nature but, due to the geographical localization of their catch site, indicates the risk of spreading the virus in natural waters.

As has been shown in studies, AngHV-1 is disseminated in many countries across Europe, although its diagnostics is not coordinated in any way. Countries in which eel management programmes have been imple- mented, including Poland, should pay particular attention to the risk of transferring AngHV-1 into waters in which the virus has not arrived yet. It is not indicated to perform reintroduction with infected eels, and according to this study, an average of $30 \%$ of the investigated eels carried the virus. Due to the homogeneity of the analysed sequence with the sequence obtained in the first HVA detection in Poland (9), the virus probably does not mutate as frequently as, e.g., koi herpes virus. However, the genetic stability and affinity of the isolates do not decrease the risk associated with the species tropism of AngHV-1. The results presented in this study clearly indicate the risk posed by mass kills of the European eel in domestic waters after the introduction of the herpesvirus AngHV-1 from imported fish.

\section{References}

1. Altschul S., Gish W., Miller W., Myers E. W., Lipman D. J.: Basic local alignment search tool. J. Mol. Biol. 1990, 215, 403-410.

2. Armitage J., Hewlett N. R., Twigg M., Lewin N. C., Reading A. J., Williams C. F., Aprahamian M., Way K., Feist S. W., Peeler J.: Detection of Herpesvirus anguillae during two mortality investigation of wild European eel in England: implications for fishery management. Fisheries Manag. Ecol. 2014, 21, 1-12.

3. Beurden S. J. van, Bossers A., Voorbergen-Laarman M. H., Haenen O. L., Peters S., Abma-Henkens M. H., Peeters B. P., Rottier P. J., Engelsma M. Y.: Complete genome sequence and taxonomic position of anguillid herpesvirus 1 . J. Gen. Virol. 2010, 91, 880-887.

4. Haenen O., Ginneken V., Engelsma M., Thillart G.: Impact of eel viruses on the recruitment of European eel, [in:] Thillart G., Dufour S., Rankin C. (eds): Spawning Migration of the European Eel. Springer Science+Business Media B.V., Dordrecht, Netherlands 2009, pp. 387-400.

5. Haenen O. L. M., Lehmann J., Engelsma M. Y., Sturenberg F.-J., Roozenburg I.: The status of European silver eels, Anguilla anguilla, in the Dutch River Rhine Watershed and Lake Ijsselmeer. Aquaculture 2010, 309, 15-24.

6. Hall T. A.: BioEdit: a user-friendly biological sequence alignment editor and analysis program for Windows 95/98/NT. Nucleic Acids Symp. Ser. 1999, 41, 95-98.

7. Hedrick R. P., Sano T.: Herpesviruses of fishes, [in:] Ahne E. Kurstak W. (ed): Viruses of Lower Vertebrates. Springer-Verlag, Berlin 1989, pp. 161-170.

8. Jakob E., Neuhaus H., Steinhagen D., Luckhardt B., Hanel R.: Monitoring of Herpesvirus anguillae (HVA) infections in European eel, Anguilla anguilla (L.), in northern Germany. J. Fish Dis. 2009, 32, 557-561.

9. Kempter J., Hofsoe P., Panicz R., Bergmann S. M.: First detection of anguillid herpesvirus 1 (AngHV-1) in European eel (Anguilla anguilla) and American eel (Anguilla rostrata) in Poland. Bull. Eur. Assoc. Fish Pat. 2014, 34, 87-94.

10. Kietpiński M., Kempter J., Panicz R., Sadowski J., Schütze H., Ohlemeyer S., Bergmann S. M.: Detection of KHV in Freshwater Mussels and Crustaceans from Ponds with KHV History in Common Carp (Cyprinus carpio). Isr. J. Aquacult. Bami. 2010, 62, 28-37.

11. Plan zagospodarowania zasobami węgorza w Polsce. Morski Instytut Rybacki w Gdyni, Instytut Rybactwa Śródlądowego w Olsztynie, Warszawa 2008, pp. 89. [In Polish: Eel management plan in Poland. National Marine Fisheries Research Institute in Gdynia, Inland Fisheries Institute in Olsztyn].

12. Report on the implementation of the polish eel management plan in 2009-2011. Morski Instytut Rybacki w Gdyni, Instytut Rybactwa Śródlądowego w Olsztynie, Warszawa, June 2012, pp. 47.

13. Rijsewijk F., Pritz-Verschuren S., Kerkhoff S., Botter A., Willemsen M., van Nieuwstadt T., Haenen O.: Development of polymerase chain reaction for the detection of Anguillid herpesvirus DNA in eels based on the herpesvirus DNA polymerase gene. J. Virol. Methods 2005, 124, 8887-8894.

14. Sano M., Fukuda H., Sano T.: Isolation and characterization of a new herpesvirus from eel, [in:] Perkins F. O., Cheng T. C. (ed.): Pathology in Marine Sciences. Academic Press, San Diego 1990, pp. 15-31.

15. Scheinert P., Baatch C.: Untersuchungen zum Vorkommen des Herpesvirus anguillae (HVA) in den Aalpopulationen bayerischer gewaesser. Fischer und Teichwirt. 2006, 8, 289-291.

16. Tamura K., Dudley J., Nei M., Kumar S.: MEGA4: Molecular evolutionary genetics analysis (MEGA) software version 4.0. Mol. Biol. Evol. 2007, 24, 1596-1599.

Corresponding author: MSc, PhD, DSc Jolanta Kempter, Kazimierza Królewicza 4, 71-550 Szczecin, Poland; e-mail: jolanta.kempter@zut.edu.pl 